\title{
Redox properties and prooxidant cytotoxicity of a neuroleptic agent 6,7-dinitrodihydroquinoxaline-2,3-dione (DNQX)
}

\author{
Jonas Šarlauskas' ${ }^{1}$ Aušra Nemeikaitè-Čènienè2 ${ }^{2}$ Lina Misevičienè1, Kastis Krikštopaitis', \\ Žilvinas Anusevičius ${ }^{1}$ and Narimantas Čènas ${ }^{1{ }^{1}}$
}

IInstitute of Biochemistry of Vilnius University, Vilnius, Lithuania; ${ }^{2}$ Center of Innovative Medicine, Vilnius, Lithuania

\begin{abstract}
In order to characterize the possible mechanism(s) of cytotoxicity of a neuroleptic agent 6,7-dinitrodihydroquinoxaline-2,3-dione (DNQX) we examined the redox properties of DNQX, and its mononitro- (NQX) and denitro- (QX) derivatives. The irreversible electrochemical reduction of the nitro groups of DNQX was characterized by the reduction peak potentials $\left(E_{p, 7}\right)$ of $-0.43 \mathrm{~V}$ and $-0.72 \mathrm{~V}$ vs. $\mathrm{Ag} / \mathrm{AgCl}$ at $\mathrm{pH} 7.0$, whereas NQX was reduced at $E_{p, 7}=-0.67 \mathrm{~V}$. The reactivities of DNQX and NQX towards the single-electron transferring enzymes NADPH:cytochrome $\mathrm{P}-450$ reductase and NADPH:adrenodoxin reductase/adrenodoxin complex were similar to those of model nitrobenzenes with the single-electron reduction potential $\left(\mathrm{E}_{7}^{1}\right)$ values of -0.29 V - -0.42 V. DNQX and NQX also acted as substrates for two-electron transferring mammalian $\mathrm{NAD}(\mathrm{P}) \mathrm{H}$ :quinone oxidoreductase (DT-diaphorase). The cytotoxicity of DNQX in bovine leukemia virus-transformed lamb kidney fibroblasts (line FLK) was prevented by antioxidants and an inhibitor of NQO1, dicoumarol, and was enhanced by the prooxidant alkylating agent 1,3-bis(2-chloromethyl)1-nitrosourea. A comparison with model nitrobenzene compounds shows that the cytotoxicity of DNQX and NQX reasonably agrees with the ease of their electrochemical reduction, and/or their reactivities towards the used enzymatic single-electron reducing systems. Thus, our data imply that the cytotoxicity of DNQX in FLK cells is exerted mainly through oxidative stress.
\end{abstract}

Key words: DNQX; flavoenzymes; cytotoxicity; oxidative stress

Received: 22 February, 2013; revised: 22 May, 2013; accepted: 03 June, 2013; available on-line: 13 June, 2013

\section{INTRODUCTION}

Nitroaromatic and nitroheterocyclic compounds $(\text { ArNO })_{2}$ comprise several important groups of redox active drugs and toxic environmental pollutants (Knox \& Chen, 2004; Orna \& Mason, 1989, and references therein). Their cytotoxicity and/or therapeutic action are mainly related to the bioreductive activation: i) flavoenzymes dehydrogenases-electrontransferases, e.g., NADPH:cytochrome P-450 reductase (P-450R, EC 1.6.2.4) perform the single-electron reduction of $\mathrm{ArNO}_{2}$ into their anion-radicals $\left(\mathrm{ArNO}_{2}^{-}\right)$, which further undergo redox cycling in the presence of oxygen with the formation of superoxide $\left(\mathrm{O}_{2}^{-*}\right)$ and the other reactive oxygen species (ROS) (Orna \& Mason, 1989; Čenas et al., 1994, and references therein), and ii) flavoenzymes dehydrogenases-transhydrogenases, e.g., mammalian DT- diaphorase $(\mathrm{NAD}(\mathrm{P}) \mathrm{H}$ : quinone oxidoreductase, NQO1, EC 1.6.99.2) or bacterial oxygen-insensitive nitroreductases reduce nitroaromatic compounds in two subsequent two-electron transfers into hydroxylamines, which alkylate DNA and other cellular nucleophiles (Knox \& Chen, 2004; Misevičienè et al., 2006; Nivinskas et al., 2001, and references therein).

6,7-Dinitrodihydroquinoxaline-2,3-dione, commonly known as 6,7-dinitroquinoxaline-2,3-dione (DNQX, Fig. 1), is a potent antagonist of a receptor of 2-amino3-(3-hydroxy-5-methyl-isoxazol-4-yl)-propanoic acid and kainic acid, extensively used in studies of neurophysiology and the treatment of nervous diseases (Martin et al., 2003, and references therein). The presence of prooxidant nitro groups in its structure points to the possibility of the oxidative stress-type cytotoxicity, which may represent an important side-effect. Some data demonstrate the DNQX-induced generation of $\mathrm{H}_{2} \mathrm{O}_{2}$ in cultured neurons (Copin et al., 1998). On the other hand, the other reports point to an antioxidant action of this compound (Kim \& Kwon, 1999; Sivakumar et al., 2013; Sun et al., 2012).

Taken together, these data warrant a thorough examination of the redox properties of DNQX with their possible impact on its postulated prooxidant cytotoxicity. In this paper, we analyze the redox properties of DNQX and its mononitro- (NQX) and denitro- (QX) derivatives, including their electrochemical characteristics, the reactivity towards relevant single- and two-electron-transferring flavoenzymes, and mammalian cell cytotoxicity.

\section{MATERIALS AND METHODS}

Chemicals and enzymes. 6,7-Dinitrodihydroquinoxaline-2,3-dione (DNQX), 6-nitrodihydroquinoxaline-2,3dione (NQX), and dihydroquinoxaline-2,3-dione (QX) (Fig. 1) were synthesized by the established methods (Deng et al., 2011; Kaupp \& Naimi-Jamal, 2002; McQuaid et al., 1992), their purity was checked by m.p., elemental analysis, ${ }^{1} \mathrm{H}-\mathrm{NMR}$ spectra, and HPLC (LaChrom,

e-mail: narimantas.cenas@bchi.vu.It

Abbreviations: ADR, NADPH:adrenodoxin reductase, ADX adrenodoxin; $\mathrm{ArNO}_{2}$, aromatic nitrocompound; $\mathrm{BCNU}, 1,3$-bis(2chloromethyl)-1-nitrosourea; $\mathrm{CL}_{50}$, concentration causing $50 \%$ cell death; DNQX, 6,7-dinitrodihydroquinoxaline-2,3-dione; DPPD, $N, N^{\prime}$ diphenyl-p-phenylene diamine; $E^{1}$, single-electron reduction potential at $\mathrm{pH} 7.0 ; E_{\mathrm{p}, 7}$, electrochemical reduction peak potential at $\mathrm{pH}$ 7.0; $\mathrm{LD}_{50}$ median lethal dose; NHE, normal hydrogen electrode; NQO1, NAD(P)H:quinone oxidoreductase; NQX, 6-nitrodihydroquinoxaline-2,3-dione; $\mathrm{P}-450 \mathrm{R}, \mathrm{NADPH}$ :cytochrome $\mathrm{P}-450$ reductase; $\mathrm{QX}$, dihydroquinoxaline-2,3-dione; ROS, reactive oxygen species 
Merck-Hitachi). Other compounds were obtained from Sigma-Aldrich and used as received. Recombinant rat NADPH:cytochrome P-450 reductase (P-450R), recombinant bovine NADPH:adrenodoxin reductase (ADR) and adrenodoxin (ADX) were prepared by the established methods (Pechurskaya et al., 2007). The enzyme concentrations were determined according to $\varepsilon_{456}=21.4$ $\mathrm{mM}^{-1} \mathrm{~cm}^{-1}$ (P-450R), $\varepsilon_{450}=11.3 \mathrm{mM}^{-1} \mathrm{~cm}^{-1}$ (ADR), and $\varepsilon_{414}=9.8 \mathrm{mM}^{-1} \mathrm{~cm}^{-1}$ (ADX). P-450R, ADR, and ADX were a generous gift of Professor Sergey Usanov and Dr. Alexey Yantsevich (Institute of Bioorganic Chemistry of Belarus Academy of Sciences, Minsk, Belarus). Rat liver DT-diaphorase (NAD(P)H:quinone oxidoreductase, NQO1) was purified according to the established method (Prochaska, 1988), its concentration was determined according to $\varepsilon_{460}=11 \mathrm{mM}^{-1} \mathrm{~cm}^{-1}$.

Electrochemical studies. Cyclic voltammetry studies were performed using a Parstat 2273 (PAR) potentiostat controlled by Power Suite electrochemical software. Glassy carbon working electrode (PAR, diameter 2 $\mathrm{mm})$, saturated $\mathrm{Ag} / \mathrm{AgCl}(+205 \mathrm{mV}$ vs. NHE) reference electrode, and auxiliary $\mathrm{Pt}$ wire electrode $\left(56 \mathrm{~mm}^{2}\right)$ were used in a standard three-electrode cirquit. The glassy carbon electrode was polished with a suspension of alumina powder $(1 \mu \mathrm{m})$ and then rinsed with deionized water. Anaerobic conditions were obtained by purging the solutions (0.05 M K-phosphate + $0.1 \mathrm{M} \mathrm{KCl,} \mathrm{pH} \mathrm{7.0,}$ $25^{\circ} \mathrm{C}$, compound concentration, 0.4-1.0 mM) with Ar for $20 \mathrm{~min}$. Stock solutions of compounds (the factor of dilution, $\geq 100$ ) were prepared in DMSO. Because of the electrode fouling during the repetitive scans in the presence of compounds, the electrochemical parameters referring only to the first scan are presented.

Enzyme kinetic studies. The enzymatic reduction of DNQX and NQX was studied spectrophotometrically using a Lambda 25 (Perkin Elmer) spectrophotometer, following the rate of the oxidation of $50 \mu \mathrm{M}$ NADPH $\left(\Delta \varepsilon_{340}=6.2 \mathrm{mM}^{-1} \mathrm{~cm}^{-1}\right)$ in the presence of nitroaromatic compound, P-450R, ADR and ADX, or NQO1. These assays were performed in $0.1 \mathrm{M} \mathrm{K}$-phosphate $(\mathrm{pH}$ 7.0) containing $1.0 \mathrm{mM}$ EDTA, at $25^{\circ} \mathrm{C}$. In the case of the ADR/ADX-assay, the concentrations of $40 \mathrm{nM}$ ADR and $1.0 \mu \mathrm{M}$ ADX were used. Their background NADPH:oxidase activities, $0.4-0.5 \mathrm{~s}^{-1}$, were substracted from the final NADPH:nitroreductase reaction rates. Because of a strong absorbance of compounds at $340 \mathrm{~nm}$, the experiments were performed in $0.2-\mathrm{cm}$ optical pathway cells. The catalytic constants of the reaction, $k_{\text {cat }}$, correspond to the number of molecules of NADPH oxidized by the enzyme active center per second. The values of $k_{\text {cat }}$ and bimolecular rate constants of reduction of DNQX and NQX, $k_{\text {cat }} / K_{\mathrm{m}}$ were obtained in a nonlinear way by a standard hyperbolic expression using SigmaPlot 2000 (version 6.1) or Statistica (version 4.30, Statsoft, 1993). In the reactions of NQO1, 0.01\% Tween 20 and $0.25 \mathrm{mg} / \mathrm{ml}$ bovine serum albumin were used as activators. The control experiments in the presence of a NADPH regeneration system, $50 \mu \mathrm{M}$ NADPH, $100 \mathrm{U} / \mathrm{ml}$ glucose-6-phosphate dehydrogenase (Sigma), and $10 \mathrm{mM}$ glucose-6-phosphate, revealed that the rise in absorbance of products of DNQX and NQX reduction by NQO1 at $340 \mathrm{~nm}$ was close to $3-5 \%$ of the NADPH oxidation rate in the absence of regeneration. The corresponding kinetic constants of NQO1 reactions were obtained after this correction.

Cell culture cytotoxicity studies. A culture of bovine leukemia virus-transformed lamb kidney fibroblasts (line FLK) was maintained in Eagle's medium supplemented with $10 \%$ fetal bovine serum at $37^{\circ} \mathrm{C}$ as de- scribed previously (Čènas et al., 2001). The FLK cells were seeded on $18 \times 18 \mathrm{~mm}$ glass slides in $5 \mathrm{ml}$ flasks in the presence or in the absence of compounds, and were grown for $24 \mathrm{~h}$. Further, the slides were rinsed 3-4 times with phosphate-buffered saline and stained with Trypan blue. The cells on the slides were counted under a light microscope. Cell viability is expressed as the percentage of viable (Trypan blue excluding) cells remaining adherent after the compound treatment with respect to their amount after $24 \mathrm{~h}$ growth in the absence of the compound. The adherent FLK cells showed 98-99\% viability, while the detached ones were found to be 98$99 \%$ nonviable.

\section{RESULTS}

\section{Electrochemical studies of DNQX and its derivatives}

The cytotoxicity of nitroaromatic compounds frequently increases with an increase in their single-electron reduction potential $\left(E_{7}^{1}\right)$, i.e., the potential of the $\mathrm{ArNO}_{2} / \mathrm{ArNO}_{2}{ }^{--}$couple (Čenas et al., 2001; Guissani et al., 1990; O'Brien et al., 1990, and references therein). It reflects an increase in their reactivity towards singleelectron transferring flavoenzymes such as P-450R or metalloproteins (Čènas et al., 2001; Marcinkevičienè et al., 1990, and references therein) and shows that the cytotoxicity is determined mainly by the redox cycling of nitroaromatics. Due to the instability of nitroaromatic anion-radicals, their $E^{1}$ values are obtained by pulseradiolysis (Wardman, 1989). Given that the values of $E^{1}$ for DNQX and NQX (Fig. 1) determined by this method are unavailable, we examined some parallel approaches including their electrochemical reduction, whose parameters may sometimes parallell their $E^{1}{ }_{7}$ values (Zuman, 1990, and references therein). The cyclic voltammograms of DNQX and NQX (Fig. 2, scans 1 and 2) have two peaks and one peak of the irreversible reduction $\left(E_{\mathrm{p}, 7}\right)$, respectively. Most probably, as observed for other nitroaromatic compounds, they reflect the four-electron reduction of their nitrogroup(s) into hydroxylamines (Zuman, 1990; Zuman et al., 1992, and references therein) (Table 1). The electrochemical reduction is controlled by the diffusion, because the reduction peak currents show a linear dependence on the square root of the potential scan rate. In the reverse scans, we also observed the quasireversible oxidation/reduction peaks of hydroxylamines and/or their secondary prod-

$$
\mathrm{R}_{1}=\mathrm{NO}_{2}, \mathrm{R}_{2}=\mathrm{H}(\mathrm{NQX})
$$

Figure 1. Formulae of DNQX and its derivatives 
Table 1. Redox properties and cytotoxicity of DNQX and its derivatives

Single-electron reduction potentials $\left(E_{7}^{1}\right)$, electrochemical reduction peak potentials $\left(E_{\mathrm{p}, 7}\right)$ at pH 7.0, bimolecular enzymatic reduction rate constants $\left(k_{\text {cat }} / K_{\mathrm{m}}\right)$, and concentrations causing $50 \%$ death of FLK cells $\left(\mathrm{cL}_{50}\right)$ of DNQX, NQX, QX, and model nitroaromatic compounds. The enzymatic and cytotoxicity studies were repeated in triplicate.

\begin{tabular}{|c|c|c|c|c|c|c|}
\hline \multirow[t]{2}{*}{ No. Compound } & \multirow[t]{2}{*}{$E_{7}^{1}(\mathrm{~V})^{\mathrm{a}}$} & \multirow[t]{2}{*}{$E_{\mathrm{p}(7)}(\mathrm{V})^{\mathrm{b}}$} & \multicolumn{3}{|c|}{$k_{\text {cat }} / K_{\mathrm{m}}\left(\mathrm{M}^{-1} \mathrm{~s}^{-1}\right)$} & \multirow{2}{*}{$\mathrm{CL}_{50}(\mu \mathrm{M})$} \\
\hline & & & $\mathrm{P}-450 \mathrm{R}$ & ADR/ADX & NQO1c & \\
\hline 1. DNQX & & $-0.43,-0.72$ & $1.2 \pm 0.1 \times 10^{5}$ & $7.9 \pm 1.4 \times 10^{5}$ & $400 \pm 120(\leq 1.0)$ & $120 \pm 10$ \\
\hline 2. NQX & & -0.67 & $1.9 \pm 0.3 \times 10^{3}$ & $2.5 \pm 0.3 \times 10^{4}$ & $\leq 50(\leq 0.05)$ & $233 \pm 15$ \\
\hline 3. QX & & & & & & $\geq 1500$ \\
\hline 4. $p$-Dinitrobenzene & -0.26 & $-0.34,-0.81$ & $1.2 \pm 0.3 \times 10^{6}$ & $2.4 \pm 0.6 \times 10^{6}$ & $1600 \pm 200(1.5 \pm 0.2)^{d}$ & $8.0 \pm 2.0^{d}, 9.2 \pm 2.2$ \\
\hline 5. o-Dinitrobenzene & -0.29 & $-0.45,-0.81$ & $2.0 \pm 0.3 \times 10^{5}$ & $2.9 \pm 0.2 \times 10^{5}$ & $660 \pm 100(\leq 0.14)^{d}$ & $30 \pm 3.0^{d}$ \\
\hline 6. $m$-Dinitrobenzene & -0.35 & $-0.56,-0.72$ & $4.9 \pm 0.9 \times 10^{4}$ & $2.1 \pm 0.2 \times 10^{5}$ & $750 \pm 100(0.33 \pm 0.05)^{d}$ & $90 \pm 20^{d}$ \\
\hline 7. $p$-Nitroacetophenone & -0.36 & -0.53 & $6.8 \pm 0.6 \times 10^{3}$ & $5.0 \pm 0.4 \times 10^{3}$ & $\leq 90(\leq 0.06)^{d}$ & $166 \pm 36^{d}$ \\
\hline 8. $p$-Nitrobenzoic acid & -0.42 & -0.67 & $1.2 \pm 0.3 \times 10^{3}$ & $8.2 \pm 0.8 \times 10^{2}$ & $100 \pm 20(\leq 0.05)^{d}$ & $780 \pm 390^{d}, 690 \pm 120$ \\
\hline
\end{tabular}

avs. NHE, taken from Wardman (1989); bvs. $\mathrm{Ag} / \mathrm{AgCl}$, this work; cThe values of $k_{\mathrm{cat}}\left(\mathrm{s}^{-1}\right)$ are given in parentheses; dFrom Čenas et al. (2001)

ucts (Zuman, 1990; Zuman et al., 1992, and references therein) (Fig. 2, scans 1 and 2). Importantly, DNQX and NQX were electrochemically inactive if the scans were performed at $-0.2-0.6 \mathrm{~V}$, i.e., before the reduction of nitroaromatic group(s) (data not shown). Besides, QX was electrochemically inactive in the entire range of the redox potentials, $-0.85 \mathrm{~V}-0.6 \mathrm{~V}$ (Fig. 2, scan 3). Thus, it shows that the 2,3-didydroxyquinoxaline (2,3-dihydroquinoxaline dione) moiety of DNQX and NQX may not contribute to their redox activity. The $E_{\mathrm{p}, 7}$ values for several model nitrobenzenes obtained under the same conditions are given for comparison, together with their experimentally determined $E_{7}^{1}$ values (Table 1 ).

\section{Enzymatic reactivity studies of DNQX and NQX}

In order to characterize the enzymatic reactivity of DNQX and NQX relevant to their cytotoxicity, we stud-

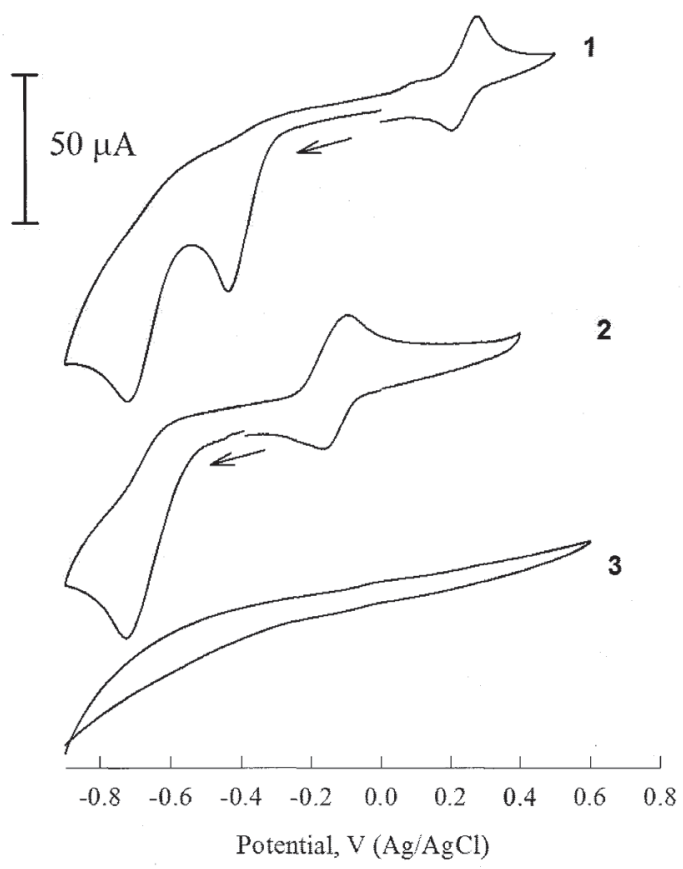

Figure 2. Electrochemistry of DNQX and its derivatives Cyclic voltammograms of DNQX (1), NQX (2), and QX (3) were recorded at $50 \mathrm{mV} / \mathrm{s}$ scan rate under anaerobic conditions, at $\mathrm{pH} 7.0$ and the compound concentration of $0.5 \mathrm{mM}$. ied their reduction by a single-electron transferring flavoenzyme P-450R, which is one of the main enzymes responsible for the oxidative stress-type cytotoxicity of nitroaromatic compounds (Čènas et al., 2001; O'Brien et al., 1990, and references therein). The $k_{\text {cat }}$ of rat P-450Rcatalyzed reactions was close to the previously reported value, $25 \mathrm{~s}^{1}$, which represents the maximal rate of $\mathrm{FMNH}^{-}$-mediated cytochrome $c$ reduction (Čènas et al., 1994). The corresponding bimolecular reduction rate constants of DNQX, NQX, and model nitrobenzene compounds $\left(k_{\mathrm{cat}} / K_{\mathrm{m}}\right)$ are given in Table 1 . In parallel, we used another model system, the adrenodoxin (ADX)dependent reduction of nitroaromatic compounds by NADPH:adrenodoxin reductase (ADR, EC 1.1.18.2). In this case, free ADR does not show a significant nitroreductase activity, and the nitroaromatic compounds are reduced by ADX, which in turn is reduced by ADR (Marcinkevičiene et al., 1990). The $k_{\text {cat }}$ of the ADR-ADX system was close to $5 \mathrm{~s}^{-1}$, which corresponds to the maximal rate of ADX reduction by ADR calculated on a two-electron base (Lambeth \& Kamin, 1979 (Fig. 3). The $k_{\text {cat }} / K_{\mathrm{m}}$ of nitroaromatic compounds in this system are also given in Table 1, showing a parallelism with the reactivities of the nitroaromatic compounds in P-450R-

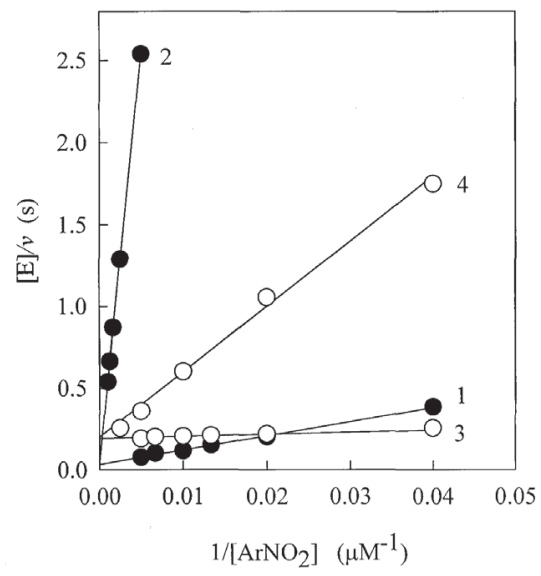

Figure 3. Kinetics of single-electron enzymatic reduction of DNQX and NQX

The rates of enzymatic oxidation of $50 \mu \mathrm{M}$ NADPH by P-450R (1, 2) or ADR-ADX (in the presence of $1.0 \mu \mathrm{M} A D X)(3,4)$, are shown in the presence of variable concentrations of DNQX $(1,3)$ or NQX $(2,4)$. 


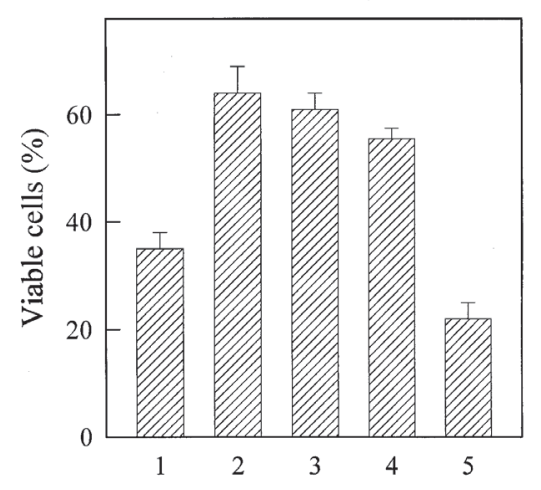

Figure 4. Modulating effects of antioxidants and enzyme inhibitors on the toxicity of DNQX in FLK cells

Concentration of DNQX, $200 \mu \mathrm{M}(1-5)$, additions: none (1), $3.0 \mu \mathrm{M}$ DPPD (2), $300 \mu \mathrm{M}$ desferrioxamine (3), $20 \mu \mathrm{M}$ dicoumarol (4), and $20 \mu \mathrm{M}$ BCNU (5), $n=3, P<0.001$ for $2-4$ against $1, P<0.01$ for 5 against 1.C

catalyzed reactions. In separate experiments, we found that in the presence of P-450R or ADR-ADX, $50 \mu \mathrm{M}$ DNQX or NQX oxidize a large excess of NADPH, 200 $\mu \mathrm{M}$. It demonstrates that DNQX and NQX undergo redox cycling in these reactions. Next, we investigated the reactivity of DNQX and MNQX towards two-electron transferring mammalian NAD $(\mathrm{P}) \mathrm{H}$ :quinone oxidoreductase (NQO1, DT-diaphorase). Their reactivity appeared to be relatively low (Table 1), which is characteristic for the reduction of nitroaromatic compounds by this enzyme (Knox \& Chen, 2004; Misevičienè et al., 2006, and references therein).

\section{Mammalian cell cytotoxicity of DNQX and its derivatives}

We studied the cytotoxicity of DNQX and its derivatives in bovine leukemia virus-transformed lamb kidney fibroblasts (line FLK), which was extensively used in our previous studies of the cytotoxicity of nitroaromatic compounds (Čènas et al., 2001, 2009). The concentrations causing 50\% cell death ( $\mathrm{cL}_{50}$ ) for DNQX and NQX (Table 1) are in the range of those for the model nitrobenzenes with $E^{1}{ }_{7}=-0.29--0.42 \mathrm{~V}$ (Table 1). In contrast, the cytotoxicity of QX was much lower (Table 1). The cytotoxicity of DNQX was partly decreased by the antioxidant N,N'-diphenyl-p-phenylene diamine (DPPD) and the iron-chelating agent desferrioxamine, and potentiated by the prooxidant 1,3-bis(2-chloroethyl)-1-nitrosourea $(\mathrm{BCNU})$, which inactivates the antioxidant enzyme glutathione reductase and depletes intracellular reduced glutathione (Öllinger \& Brunmark, 1991) (Fig. 4). This points to the prooxidant character of the cytotoxicity of DNQX. An inhibitor of NQO1, dicoumarol, partly decreased the cytotoxicity of DNQX (Fig. 4).

\section{DISCUSSION}

Our study characterizes the redox properties of DNQX which may be important in the understanding of a possible side effect of this neuroleptic agent, namely, its prooxidant (cyto)toxicity. Because the $E_{7}^{1}$ values for DNQX and NQX that could be used in the analysis of their cytotoxicity mechanisms are unavailable, some indirect and approximate information may be gained from their cyclic voltammetry and their reactivities towards single-electron transferring enzymes (Fig. 2, Table 1). The values of $E_{\mathrm{p}(7)}$ and $E_{7}^{1}$ of nitroaromatic compounds are interrelated (Zuman, 1990, and references therein), besides, there also are linear dependences of $\log k_{\text {cat }} / K_{\mathrm{m}}$ on $E^{1}{ }_{7}$ of nitroaromatics in their reactivity towards P-450R (Orna \& Mason, 1989; Ćenas et al., 1994, and references therein), or ADR-ADX (Marcinkevičiené et al., 1990). Thus, according to their electrochemical and enzymatic redox properties (Table 1), the approximate $E^{1}{ }_{7}$ values for DNQX and NQX may be close to $-0.3 \mathrm{~V}$ and -0.4 $\mathrm{V}$, respectively.

The cytotoxicity of nitroaromatic compounds in FLK and several other cell lines increases upon an increase in their $E_{7}^{1}$ with a coefficient $\Delta \log \mathrm{cL}_{50} / \Delta E^{1}{ }_{7}$ $\sim-10 \mathrm{~V}^{-1}$ (Čènas et al., 2001; Guissani et al., 1990; O'Brien et al., 1990, and references therein). Taken together with the antioxidant protection, it shows that the main factor of their cytotoxicity is the oxidative stress, initiated by enzymatic redox cycling. In the case of DNQX, the protection by DPPD and desferrioxamine, and the potentiating effect of BCNU (Fig. 4) show that the main factor of its cytotoxicity is the oxidative stress (Öllinger \& Brunmark, 1991). The $\mathrm{cL}_{50}$ of DNQX and NQX in FLK cells are in line with those for other nitroaromatic compounds with $E_{7}^{1}=-0.29 \mathrm{~V}--0.42 \mathrm{~V}$ (Table 1), which reasonably agree with their approximate values of $E_{7}^{1}$ suggested in our work. The protection by an inhibitor of NQO1, dicoumarol, against the cytotoxicity of DNQX (Fig. 4) shows that NQO1-catalyzed reactions, most probably the formation of the hydroxylamine reduction products, may also contribute to its cytotoxicity to some extent (Cènas et al., 2001). Our data also imply that the presence of dihydroquinoxaline-2,3-dione moiety in the structure of DNQX shows minor if any influence on its prooxidant cytotoxicity. Although the 2,3-dihydroxyquinoxaline tautomer of DNQX could hypothetically act as an antioxidant due to its 2,3-dihydroxynaphalene-like structure, the presence of the electron-accepting nitrogroups will significantly reduce its antioxidant capacity. It is also supported by the low cytotoxicity of QX (Table 1) which is much lower than the toxicity of redox-active flavonoids and hydroxybenzenes in this cell line (Maroziene et al., 2012). Thus, regarding the previously reported antioxidant properties of DNQX, one may suggest that they reflect the superposition of two opposite factors, namely its general prooxidant activity and the inhibition of kainate receptors, whose overstimulation by kainate leads to the formation of ROS and NO with a subsequent formation of peroxynitrite (Kim \& Kwon, 1999; Martinez-Palma et al., 2003; Sivakumar et al., 2013; Sun et al., 2012). Possibly, the latter mechanism plays a major role in the action of DNQX in neuronal cells, whereas its prooxidant activity plays a major role in the action against other cell types.

Finally, our study provides some insight on the potential toxic properties of DNQX which, according to our best knowledge, have not been studied so far. Because the cytotoxicity of DNQX and MNQX is similar to that of (poly)nitrobenzenes with similar single-electron reduction potentials (Table 1), it is reasonable to suggest that the toxicity of DNQX may be similar to that of $m$-dinitrobenzene, whose median lethal dose $\left(\mathrm{LD}_{50}\right.$, rats, peroral administration) is equal to $0.5 \mathrm{mmol} / \mathrm{kg}$ (83 $\mathrm{mg} / \mathrm{kg}$ ) (http://toxnet.nlm.nih. gov/). In turn, the peroral toxicity of MNQX in rats may be similar to that of $p$-nitrobenzoic acid $\left(\mathrm{LD}_{50}=\right.$ $11.8 \mathrm{mmol} / \mathrm{kg}(1960 \mathrm{mg} / \mathrm{kg})$, determined under similar conditions. 


\section{REFERENCES}

Čènas N, Anusevičius Ž, Bironaite D, Bachmanova GI, Archakov AI, Öllinger K (1994) The electron transfer reactions of NADPH:cytochrome P-450 reductase with nonphysiological oxidants. Arch Biochem Biophys 315: 400-406.

Čènas N, Nemeikaitè-Cénienè A, Sergedienè E, Nivinskas H, Anusevičius Ž, Šarlauskas J (2001) Quantitative structure-activity relationships in enzymatic single-electron reduction of nitroaromatic explosives: implications for their cytotoxicity. Biochim Biophys Acta 1528: $31-38$

Čènas N, Nemeikaitè-Čènienè A, Šarlauskas J, Anusevičius Ž, Nivinskas H, Misevičiené L, Marozienè A (2009) Mechanisms of mammalian cell cytotoxicity of explosives. In: Ecotoxicology of Explosives. Sunahara GI, Lotufo G, Kuperman RG, Hawari J, eds, pp 211-226. CRC Press, Boca Raton, London, New York.

Copin JC, Li Y, Reola L, Chan PH (1998) Trolox and 6,7-dinitroquinoxaline-2,3-dione prevent necrosis but not apoptosis in cultured neurons subjected to oxygen deprivation. Brain Res 784: 25-36.

Deng J, Feng E, Ma S, Zhang Y, Liu X, Li H, Huang H, Zhu J, Zhu W, Shen X, Miao L, Liu H, Jiang H, Li J (2011) Design and synthesis of small molecule RhoA inhibitors: A new promising therapy for cardiovascular diseases? J Med Chem 54: 4508-4522.

Guissani A, Henry Y, Lougmani N, Hickel B (1990) Kinetic studies of four types of nitroheterocyclic radicals by pulse radiolysis. Correlation of pharmacological properties to decay rates. Free Rad Biol Med 8: 173-189.

Kaupp G, Naimi-Jamal MR (2002) Quantitative cascade condensations between $o_{-}$phenylenediamines and 1,2-dicarbonyl compounds without production of wastes. Eur J Org Chem 8: 1368-1373.

Kim HJ, Kwon JS (1999) Effects of placing micro-implants of melatonin in striatium on oxidative stress and neuronal damage mediated by $N$-methyl- $D$-aspartate (NMDA) and non-NMDA receptors. Arch Pharm Res 22: 35-43.

Knox RJ, Chen S (2004) Quinone reductase-mediated nitroreduction: clinical applications. Methods Enzymol 382B: 194-221.

Lambeth JD, Kamin H (1979) Adrenodoxin reductase-adrenodoxin complex. Flavin to iron-sulfur electron transfer as the rate-limiting step in the NADPH-cytochrome $c$ reductase reaction. $J$ Biol Chem. 254: 2766-2774

Marcinkevičienė J, Čènas N, Kulys J, Usanov SA, Sukhova NM, Selezneva IS, Gryazev VF (1990) Nitroreductase reactions of the NADPH:adrenodoxin reductase and the adrenodoxin complex. Biomed Biochim Acta 49: 167-172.

Maroziené A, Nemeikaitè-Čenienè A., Vidžiūnaitè R, Čènas N (2012) Correlation between mammalian cell cytotoxicity of flavonoids and the redox potential of phenoxyl radical/phenol couple. Acta Biochim Pol 59: 299-305.

Martin A, Recasens M, Guiramand J (2003) DNQX-induced toxicity in cultured rat hippocampal neurons: an apparent AMPA receptorindependent effect? Neurochem Int 42: 251-260.

Martinez-Palma L, Pehar M, Cassina P, Peluffo H, Castellanos R, Anesetti G, Beckman JS, Barbeito L (2003) Involvement of nitric oxide on kainate-induced toxicity in oligodendrocyte precursors. Neurotox Res 5: 399-406.

McQuaid LA, Smith ECR, South KK, Mitch CH, Schoepp DD, Darryle D, True RA, Calligaro DO, O'Malley PJ, Lodge D, Ornstein PL (1992) Synthesis and excitatory amino acid pharmacology of a series of heterocyclic-fused quinoxalinones and quinazolinones. $J$ Med Chem 35: 3319-3324.

Misevičienè L, Anusevičius Ž, Šarlauskas J. Čènas N (2006) Reduction of nitroaromatic compounds by $\mathrm{NAD}(\mathrm{P}) \mathrm{H}$ :quinone oxidoreductase (NQO1): the role of electron-accepting potency and structural parameters in the substrate specificity. Acta Biochim Pol 53: 569-576.

Nivinskas H, Koder RL, Anusevičius Ž, Šarlauskas J, Miller A-F, Čenas N (2001) Quantitative structure-activity relationships in twoelectron reduction of nitroaromatic compounds by Enterobacter cloacae NAD(P)H:nitroreductase. Arch Biochem Biophys 385: 170-178.

O'Brien PJ, Wong WC, Silva J, Khan S (1990) Toxicity of nitrobenzene compounds towards isolated hepatocytes: dependence on reduction potential. Xenobiotica 20: 945-955.

Öllinger K, Brunmark A (1991) Effects of hydroxyl substituent position on 1,4-naphthoquinone toxicity to rat hepatocytes. J Biol Chem 266: 21496-21503.

Orna MV, Mason RP (1989) Correlation of kinetic parameters of nitroreductase enzymes with redox properties of nitroaromatic compounds. J Biol Chem 264: 12379-12384.

Pechurskava TA, Harnastai IN, Grabovec IP, Gilep AA, Usanov SA (2007) Adrenodoxin supports reactions catalyzed by microsomal streoidgenetic cytochrome P450s. Biochem Biophys Res Commun 353: 598-604.

Prochaska HJ (1988) Purification and crystallization of ral liver NAD(P)H:(quinone-acceptor) oxidoreductase by cibacron blue affinity chromatography: identification of a new and potent inhibitor. Arch Biochem Biophys 267: 529-538.

Sivakumar V, Foulds WS, Luu CD, Ling EA, Kaur C (2013) Hypoxia-induced ganglion cell damage through activation of AMPA receptors and the neuroprotective effects of DNQX. Exp Eye Res doi:pii:S0014-4835 (13) 00006-7.10.1016/jexer.2013.01.04

Sun CM, Wang DJ, Zheng WH (2012) Hydrogen peroxide attenuates the prosurvival signaling of insulin-like growth factor-1 through two pathways. Neuroreport, 23: 768-773.

Wardman P (1989) Reduction potentials of one-electron couples involving free radicals in aqueous solutions. J Phys Chem Ref Data 18: $1637-1755$.

Zuman P (1990) Redox systems generated by electrochemical oxidations and reductions. In: NATO Advanced Research Workshop on Selective Activation of Drugs by Redox Processes. Adams GE, Breccia A, Fielden EM, Wardman, P, eds, pp 39-51. Plenum Press, New York.

Zuman P, Fijalek Z, Dumanovic D, Suznjevic D (1992) Polarographic and electrochemical studies of some aromatic and heterocyclic nitro-compounds. 1. General mechanistic aspects. Electroanalysis 4: 783-794. 